\title{
Comparative Disposition Kinetics of Meloxicam Following a Single Intravenous Bolus Dose and Its Concurrent Administration with Ofloxacin in Yak and Cattle
}

\author{
Fakar Uddin Ali Ahmed², Rajkumar Singh Yadav² and Satish Kumar Garg ${ }^{\text {** }}$ \\ ${ }^{1}$ Department of Pharmacology and Toxicology, College of Veterinary Science and Animal Husbandry, UP, India \\ ${ }^{2}$ Deen Dayal Upadhyaya Pashu-Chikitsa Vigyan Vishwavidyalaya Evam Go Anusandhan Sansthan, Mathura, India
}

\begin{abstract}
Present study describes the comparative pharmacokinetic (PK) profile of meloxicam $\left(0.5 \mathrm{mg} \cdot \mathrm{kg}^{-1}\right)$ alone its concurrent administration with ofloxacin $\left(7.5 \mathrm{mg} \mathrm{kg}^{-1}\right)$ by intravenous route in yak and cattle. Plasma concentration of meloxicam was determined by HPLC assay and pharmacokinetic parameters by compartmental method using "PHARMKIT" software. Following intravenous administration of meloxicam alone, $\mathrm{t}_{1 / 2 \alpha}, \mathrm{t}_{1 / 2 \beta}, \mathrm{AUC}, \mathrm{Vd}_{\text {area }}$ and $\mathrm{Cl}_{\mathrm{B}}$ values were found to be $0.21+0.04 \mathrm{~h}, 4.65+0.40 \mathrm{~h}, 25.46+1.22 \mu \mathrm{g} / \mathrm{ml} . \mathrm{h}, 1.97+0.11 \mathrm{~L} / \mathrm{kg}$ and $0.35+0.02 \mathrm{~L} / \mathrm{h} / \mathrm{kg}$ respectively in yak and all these values were almost comparable to those found in cattle. But the values of $\mathrm{K}_{12} / \mathrm{K}_{21} \mathrm{~V}_{\mathrm{c}}$, $V_{p}$ and $f_{c}$ differed significantly between yak and cattle. Further, no significant differences were observed in values of majority of the pharmacokinetic parameters between meloxicam alone or its concurrent administration with ofloxacin in yak and cattle except the values of $V_{c}, V_{p}$ and T/P which differed significantly between alone and concurrent administration in yak but not in cattle. Based on pharmacokinetic variables, the loading and maintenance doses of meloxicam were found to be 1.05 and $0.88 \mathrm{mg} \cdot \mathrm{kg}^{-1}$ body weight for yak and 0.97 and $0.79 \mathrm{mg}^{\mathrm{kg}} \mathrm{g}^{-1}$ for cattle and be repeated at $12 \mathrm{~h}$ interval. Results of present study further suggest that important pharmacokinetic parameters do not significantly differ between yak and cattle and meloxicam can be used at same dose levels in both the species and adjustment in dosage regimen of meloxicam is not warranted in either of the species, if to be used concurrently with ofloxacin.
\end{abstract}

Keywords: Pharmacokinetics; Drug interaction; Meloxicam; Ofloxacin; Cattle; Yak

\section{Introduction}

Meloxicam (4-hydroxy-2-methyl-N-(5-methyl-2-thiazolyl)-2H, 1, 2-benzothaizine-3-carboxamide-1, 1-dioxide) is one of the most commonly employed non-steroidal anti-inflammatory drugs (NSAID) in veterinary clinical practice as it preferentially inhibits COX-2, its bioavailability is optimum and it has long elimination half-life. These attributes make it an ideal and suitable NSAID for use in animals [1]. It is approved for use in cattle in European Union (EU) as adjunct therapy for acute respiratory disease, diarrhoea and acute mastitis along with other drugs [2].

Disposition kinetics of meloxicam has been investigated in horses [3-5], cattle [6], buffaloes [7], sheep and goats [8], dogs, mini-pigs, rats and baboons [1], piglets [9] human beings [10,11] and ferrets [12]. However, there is no information on disposition kinetics of meloxicam in yak (Poephagus grunniens L.), which is one of the best sustainable animal resource of highlanders ( $>3000$ meters above mean sea level) of India, Peoples' Republic of China, Mongolia and certain other countries.

Antibacterials and anti-inflammatory drugs are often used concomitantly both in human and veterinary clinical practice. Fluoroquinolones have been reported to interact with NSAIDs at pharmacokinetic and pharmacodynamic level [13]. On concurrent administration of quinolones with NSAID (fenbuten), serious convulsions have been reported in laboratory animals [14]. Alterations in PK determinants of ciprofloxacin due to aspirin in rabbits [15], meloxicam due to gatifloxacin in buffaloes [16] and meloxicam due to enrofloxacin in turkeys [17] have been reported. But diclofenac sodium failed to significantly alter PK profile of enrofloxacin in calves [18]. Ofloxacin, a broad spectrum second generation fluoroquinolone, can be used concomitantly with meloxicam in veterinary clinical practice. Therefore, target-species specific data on pharmacokinetic interaction between these two drugs is required for its rational use. Comparative study in yak and cattle will help in unraveling the species-dependent disposition kinetic differences between these two ruminant species which have certain anatomical, physiological or biochemical similarities and differences. Due to paucity of data on pharmacokinetics of various drugs in yak, dosage regimens are often extrapolated from cattle and buffaloes. Therefore, the present study was undertaken to generate species-specific data on disposition kinetics of meloxicam in yak and cattle following a single intravenous bolus dose and also to compare the respective data with that after concomitant administration of meloxicam and ofloxacin.

\section{Materials and Methods}

\section{Experimental animals}

Five healthy adult male yak (Poephagus grunniens L.) having an average body weight of $300 \mathrm{~kg}$ and five adult male cattle (Bos indicus) having an average body weight $250 \mathrm{~kg}$ were used in the present study.

*Corresponding author: Satish Kumar Garg, Department of Veterinary Pharmacology \& Toxicology, UP, India, Tel: 09456054995; Fax: 0565-2471288; E-mail: profsatish@gmail.com

Received September 23, 2015; Accepted December 11, 2015; Published December 15, 2015

Citation: Ahmed FUA, Yadav RS, Garg SK (2015) Comparative Disposition Kinetics of Meloxicam Following a Single Intravenous Bolus Dose and Its Concurrent Administration with Ofloxacin in Yak and Cattle. J Bioanal Biomed 7: 197-202. doi:10.4172/1948-593X.1000144

Copyright: (c) 2015 Ahmed FUA, et al. This is an open-access article distributed under the terms of the Creative Commons Attribution License, which permits unrestricted use, distribution, and reproduction in any medium, provided the original author and source are credited. 
Yaks were kept at Nyukmadung Farm of National Research Centre on Yak (ICAR), Dirang, Arunachal Pradesh, India at an altitude of 8,500 $\mathrm{ft}$. above msl and cattle were kept at the experimental farm of the same Institute at an altitude of $5000 \mathrm{ft}$. above msl. Animals were maintained on standard concentrate mixture, seasonal green fodder and paddy straw. Water was provided ad libitum.

\section{Drugs and chemicals}

For preparation of standard curve, meloxicam was procured from the Sigma Aldrich, USA, and commercially available injectable formulation of meloxicam (Melonex, INTAS Pharmaceutical Ltd) was used for administration in animals. Technical grade ofloxacin was procured from Ranbaxy for standardization of HPLC method and $10 \%$ ofloxacin solution ( $\mathrm{pH} 7.5-8.0)$ was prepared in laboratory for administration.

\section{Experimental design}

Study was undertaken in two phases; in phase I, meloxicam alone was administered while in phase II, meloxicam and ofloxacin were administered concurrently to the same animals after a wash out period of 21 days.

\section{Dosing and sampling}

Meloxicam was administered at the dose rate of $0.5 \mathrm{mg} \cdot \mathrm{kg}^{-1}$ body weight and ofloxacin at $7.5 \mathrm{mg} \cdot \mathrm{kg}^{-1}$ body weight by intravenous route. For concomitant administration of these two drugs, same route and same doses of both the drugs were used but both were administered into contra-lateral jugular veins. Blood samples were collected by jugular venipuncture into heparinised tubes at 0 (prior to drug administration) and at 2.5, 5, 10, 20,30, $45 \mathrm{~min}$ and 1, 2, 3, 4, 6, 8, $10,12,24,36,48,72$ and 96 h post-drug administration. Plasma was harvested by centrifugation at 3000 revolution $\mathrm{min}^{-1}$ for $15 \mathrm{~min}$ and stored at $-20^{\circ} \mathrm{C}$ till analyzed.

\section{Assay method}

Plasma proteins were precipitated using $70 \%$ perchloric acid and acetonitrile mixture $(1: 1 \mathrm{v} / \mathrm{v})$. Supernatant was filtered through a 0.22 $\mu \mathrm{m}$ membrane filter and transferred to another tube. A $20 \mu \mathrm{l}$ of aliquot was injected into the HPLC system. Meloxicam concentrations in plasma at different time intervals were determined by modified HPLC method [19]. The mobile phase used was consisted of $60 \%$ of buffer (170 mmol of sodium acetate buffer adjusted to $\mathrm{pH} 3.3$ with glacial acetic acid) and $40 \%$ acetonitrile. The flow rate of mobile phase was 1 ml.min ${ }^{-1}$ and the eluent was monitored with dual $\lambda$ absorbance detector with the wavelength setting at $355 \mathrm{~nm}$.

Standard curve of meloxicam was prepared in the concentration range of 0.01 to $100 \mu \mathrm{g} / \mathrm{ml}$. Working plasma standards were prepared from stock solutions of meloxicam after diluting with pooled plasma from untreated animals. The standards so prepared were processed and analyzed. The standard curve was found to be linear and reproducible with the correlation coefficient $\left(r^{\wedge} 2\right)$ value of 0.9914 and mean interday coefficient of variance of 6.59 per cent. The mean recovery of meloxicam from yak and cattle plasma was more than $90 \%$. Blank plasma did not produce any endogenous interference on retention time of meloxicam.

\section{Pharmacokinetic analysis}

Plasma concentrations versus time data of meloxicam were subjected to pharmacokinetic analysis with an interative least square non-linear regression programme using "PHARMKIT" software and other parameters were determined using the standard equations $[20,21]$.

\section{Statistical analysis of data}

The data generated in the present studies were subjected to statistical analysis by employing Student's t-test [22].

\section{Results}

Plasma levels and pharmacokinetic determinants of meloxicam following administration of a single intravenous bolus dose

Following single intravenous bolus dose @0.5 mg. $\mathrm{kg}^{-1}$ in yak, plasma concentrations of meloxicam (mean $\pm \mathrm{SE}$ ) versus time data of yak are depicted in Figure 1. Mean peak plasma meloxicam level was found to be $5.60 \pm 0.24 \mu \mathrm{g} \cdot \mathrm{ml}^{-1}$ at $2.5 \mathrm{~min}$, which declined to $1.82 \pm 0.03 \mu \mathrm{g} \cdot \mathrm{ml}^{-1}$ at $4 \mathrm{~h}$, and thereafter gradually to $0.21 \pm 0.05 \mu \mathrm{g} \cdot \mathrm{ml}^{-1}$ at $24 \mathrm{~h}$. Plasma levels versus time data of meloxicam was best fitted to a two-compartment open model and adequately described by the biexponential equation:

$$
\mathrm{C}_{\mathrm{p}}=\mathrm{Ae}^{-\mathrm{at}}+\mathrm{Be}^{-\beta \mathrm{t}}
$$

Where, $C_{p}$ is the plasma concentration of meloxicam at time $t$; A and $B$ are the zero time intercepts of distribution $(\alpha)$ and elimination $(\beta)$ phases, respectively; and "e" is the base of natural logarithm. Pharmacokinetic parameters determined and derived from the above determinants following IV administration of meloxicam in yak are summarized in Table 1.

Following single intravenous dose of meloxicam $\left(0.5 \mathrm{mg} \cdot \mathrm{kg}^{-1}\right)$, plasma concentrations of meloxicam in cattle are depicted in Figure 2. Mean peak plasma meloxicam level at $2.5 \mathrm{~min}$ was found to be slightly higher $\left(6.41 \pm 0.12 \mu \mathrm{g} \cdot \mathrm{ml}^{-1}\right)$ than in yak and it declined to $3.24 \pm 0.04$ $\mu \mathrm{g} . \mathrm{ml}^{-1}$ within $1 \mathrm{~h}$, and thereafter, gradually to $0.15 \pm 0.02 \mu \mathrm{g} \cdot \mathrm{ml}^{-1}$ at $24 \mathrm{~h}$. Figure 3 depicts the comparative mean plasma meloxicam levels in yak and cattle following IV administration and it is evident from the data that plasma level of test drug did not differ significantly between yak and cattle. Disposition of meloxicam in cattle too was best described by two-compartment open model as in yak. Different disposition kinetic determinants describing the distribution and elimination characteristics of meloxicam in yak and cattle are summarized in Table 1 .

Plasma levels and pharmacokinetics of meloxicam following concurrent intravenous administration of meloxicam (0.5 mg.kg-1) and ofloxacin (7.5 mg.kg $\left.{ }^{-1}\right)$

Mean plasma levels of meloxicam following concurrent intravenous administration of meloxicam and ofloxacin as function of time in yak and cattle are depicted in Figures 1 and 2, respectively. Peak plasma meloxicam level was found to be $6.26 \pm 0.17 \mu \mathrm{g} \cdot \mathrm{ml}^{-1}$ at $2.5 \mathrm{~min}$, which rapidly declined to $3.95 \pm 0.02 \mu \mathrm{g} \cdot \mathrm{ml}^{-1}$ within $45 \mathrm{~min}$ and thereafter, gradually to $0.13 \pm 0.01 \mu \mathrm{g} \cdot \mathrm{ml}^{-1}$ at $24 \mathrm{~h}$ in yak (Figure 1). Figure 2 depicts the mean plasma levels of meloxicam in cattle following concurrent intravenous administration of meloxicam and ofloxacin. Perusal of data revealed plasma meloxicam level of $6.41 \pm 0.05 \mu \mathrm{g} \cdot \mathrm{ml}^{-1}$ at $2.5 \mathrm{~min}$ which gradually declined to $0.14 \pm 0.04 \mu \mathrm{g} . \mathrm{ml}^{-1}$ at $24 \mathrm{~h}$. After concurrent administration of the two-drugs also, meloxicam could be detected in plasma of both yak and cattle up to $24 \mathrm{~h}$.

Comparison of mean plasma levels of meloxicam following its 
Citation: Ahmed FUA, Yadav RS, Garg SK (2015) Comparative Disposition Kinetics of Meloxicam Following a Single Intravenous Bolus Dose and Its Concurrent Administration with Ofloxacin in Yak and Cattle. J Bioanal Biomed 7: 197-202. doi:10.4172/1948-593X.1000144

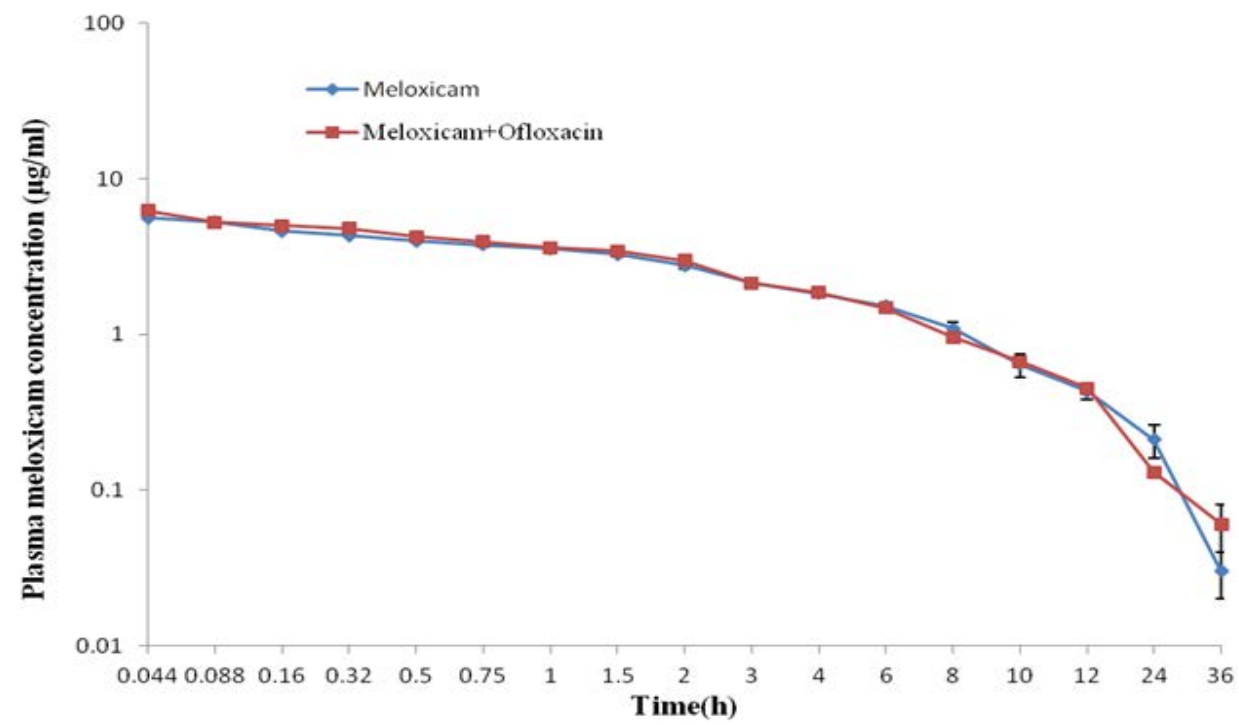

Figure 1: Semi logarithmic plot of comparative meloxicam levels following a single intravenous administration of meloxicam (0.5 mg/kg) alone and concurrent administration of meloxicam $(0.5 \mathrm{mg} / \mathrm{kg})$ and ofloxacin $(7.5 \mathrm{mg} / \mathrm{kg})$ in yak. Data presented are mean $\pm \mathrm{SE}$ of five animals.

\begin{tabular}{|c|c|c|c|c|}
\hline \multirow{2}{*}{$\begin{array}{l}\text { Pharmacokinetic parameters } \\
\text { (Units) }\end{array}$} & \multicolumn{2}{|c|}{ Yak } & \multicolumn{2}{|c|}{ Cattle } \\
\hline & Meloxicam & Meloxicam+Ofloxacin & Meloxicam & Meloxicam+Ofloxacin \\
\hline $\mathrm{A}\left(\mu \mathrm{g} \cdot \mathrm{ml}^{-1}\right)$ & $2.88 \pm 0.46$ & $2.73 \pm 0.15$ & $3.16 \pm 0.09$ & $2.99 \pm 0.15$ \\
\hline $\mathrm{B}\left(\mu \mathrm{g} \cdot \mathrm{ml}^{-1}\right)$ & $3.72 \pm 0.21$ & $3.96 \pm 0.14$ & $3.54 \pm 0.18$ & $3.72 \pm 0.19$ \\
\hline$\alpha\left(h^{-1}\right)$ & $3.36 \pm 0.29$ & $3.59 \pm 0.75$ & $3.82 \pm 0.97$ & $3.97 \pm 0.90$ \\
\hline$\beta\left(h^{-1}\right)$ & $0.15 \pm 0.02$ & $0.16 \pm 0.01$ & $0.14 \pm 0.01$ & $0.15 \pm 0.01$ \\
\hline$t_{1 / 2 a}(h)$ & $0.21 \pm 0.04$ & $0.22 \pm 0.03$ & $0.24 \pm 0.06$ & $0.21 \pm 0.04$ \\
\hline$t_{1 / 2 \beta}(h)$ & $4.65 \pm 0.40$ & $4.27 \pm 0.21$ & $5.04 \pm 0.35$ & $4.86 \pm 0.39$ \\
\hline $\mathrm{AUC}\left(\mu \mathrm{g} \cdot \mathrm{ml}^{-1} \mathrm{~h}\right)$ & $25.46 \pm 1.22$ & $25.12 \pm 0.66$ & $26.53 \pm 0.94$ & $26.57 \pm 0.82$ \\
\hline AUMC $\left(\mu \mathrm{g} \cdot \mathrm{ml}^{-1} \mathrm{~h}^{2}\right)$ & $167.60 \pm 21.11$ & $150.41 \pm 10.15$ & $186.47 \pm 17.76$ & $181.38 \pm 19.60$ \\
\hline MRT (h) & $6.50 \pm 0.59$ & $5.96 \pm 0.27$ & $6.97 \pm 0.43$ & $6.77 \pm 0.50$ \\
\hline $\mathrm{Vd}_{\text {area }}\left(\mathrm{L} \cdot \mathrm{kg}^{-1}\right)$ & $1.97 \pm 0.11$ & $1.84 \pm 0.05$ & $2.05 \pm 0.09$ & $1.97 \pm 0.09$ \\
\hline $\mathrm{Vd}_{\mathrm{ss}}\left(\mathrm{L} \mathrm{kg}^{-1}\right)$ & $2.13 \pm 0.44$ & $1.96 \pm 0.37$ & $2.20 \pm 0.43$ & $2.13 \pm 0.42$ \\
\hline $\mathrm{Cl}_{\mathrm{B}}\left(\mathrm{L} \cdot \mathrm{h}^{-1} \cdot \mathrm{kg}^{-1}\right)$ & $0.35 \pm 0.02$ & $0.31 \pm 0.01$ & $0.29 \pm 0.01$ & $0.30 \pm 0.02$ \\
\hline $\mathrm{K}_{\mathrm{el}}\left(\mathrm{h}^{-1}\right)$ & $0.50 \pm 0.22$ & $0.49 \pm 0.22$ & $0.48 \pm 0.23$ & $0.48 \pm 0.23$ \\
\hline $\mathrm{K}_{12}\left(\mathrm{~h}^{-1}\right)$ & $1.97 \pm 0.11$ & $1.45 \pm 0.28$ & $1.78 \pm 0.35$ & $1.79 \pm 0.32$ \\
\hline $\mathrm{K}_{21}\left(\mathrm{~h}^{-1}\right)$ & $2.13 \pm 0.44$ & $1.98 \pm 0.62$ & $2.00 \pm 0.66$ & $2.15 \pm 0.63$ \\
\hline $\mathrm{K}_{12} / \mathrm{K}_{21}\left(\mathrm{~h}^{-1}\right)$ & $0.35^{A} \pm 0.02$ & $0.53 \pm 0.06$ & $0.67^{\mathrm{B}} \pm 0.09$ & $0.63 \pm 0.10$ \\
\hline Vc $\left(\mathrm{L} . k g^{-1}\right)$ & $0.33^{\mathrm{aA}} \pm 0.22$ & $1.47^{\mathrm{b}} \pm 0.04$ & $1.47^{\mathrm{B}} \pm 0.03$ & $1.47 \pm 0.02$ \\
\hline $\mathrm{Vp}\left(\mathrm{L} . \mathrm{kg}^{-1}\right)$ & $1.97^{\mathrm{aA}} \pm 0.11$ & $1.07^{b} \pm 0.23$ & $1.32^{B} \pm 0.20$ & $1.24 \pm 0.21$ \\
\hline T/P (ratio) & $2.13^{\mathrm{aA}} \pm 0.44$ & $0.61^{b} \pm 0.11$ & $0.59^{\mathrm{B}} \pm 0.36$ & $0.51 \pm 0.07$ \\
\hline $\mathrm{f}_{\mathrm{c}}$ (ratio) & $0.35^{A} \pm 0.02$ & $0.57 \pm 0.07$ & $0.73^{B} \pm 0.11$ & $0.68 \pm 0.11$ \\
\hline
\end{tabular}

Data presented are Mean \pm SE of five animals. Different capital superscripts in a row indicate significant difference $(P<0.05)$ between yak and cattle.Different small superscripts in a row indicate significant difference $(P<0.05)$ in yak and cattle between single versus concurrent administration. A-zero time intercept of the distribution phase; $B$-zero time intercept of the elimination phase; $t_{12 \alpha}$ distribution half-life; $t_{122}$-elimination half-life; $\alpha$-distribution rate constant; $\beta$-elimination rate constant; $A \cup C$ - total area under the plasma drug concentration time curve; AUMC-total area under the first moment of plasma drug concentration time curve; $\mathrm{K}_{\mathrm{el}}$-the elimination rate constant of the drug from central compartment; $\mathrm{K}_{21}$ - the rate constant of transfer of drug from tissues to the central compartment; $\mathrm{K}_{12}$-the rate constant of transfer of drug from the central to tissue compartment; fc - fraction of drug present in the central compartment; $\mathrm{Vd}$ - the volume of distribution of drug based on area; $\mathrm{Vc}$ - the volume of distribution of drug in central compartment; $\mathrm{V}_{\mathrm{p}}$-the volume of distribution of drug in peripheral compartment; $\mathrm{Vd}_{\mathrm{ss}}$-the volume of distribution of drug at steady state; $\mathrm{Cl}_{\mathrm{B}}$-the total body clearance of drug; T/P - ratio of the drug concentration between peripheral and the central compartment; MRT - mean residence time.

Table 1: Comparative disposition kinetic parameters (mean $\pm \mathrm{SE})$ of meloxicam following a single intravenous bolus dose administration of meloxicam alone $\left(0.5 \mathrm{mg} . \mathrm{kg}^{-1}\right)$ and after concurrent administration with ofloxacin $\left(7.5 \mathrm{mg} \cdot \mathrm{kg}^{-1}\right)$ in yak and cattle.

alone administration with those after concurrent administration with ofloxacin revealed that plasma meloxicam levels did not differ significantly between alone versus concurrent administration in yak (Figure 1) and cattle (Figure 2) except that the plasma level was found to be significantly $(\mathrm{P}<0.05)$ lower $\left(0.39 \pm 0.02 \mu \mathrm{g} \cdot \mathrm{ml}^{-1}\right)$ in cattle at $12 \mathrm{~h}$ after concurrent administration compared to that of meloxicam alone $\left(0.52 \pm 0.01 \mu \mathrm{g} \cdot \mathrm{ml}^{-1}\right)$.

Plasma meloxicam levels as a function of time were best fitted to a two-compartment open model and adequately described by 


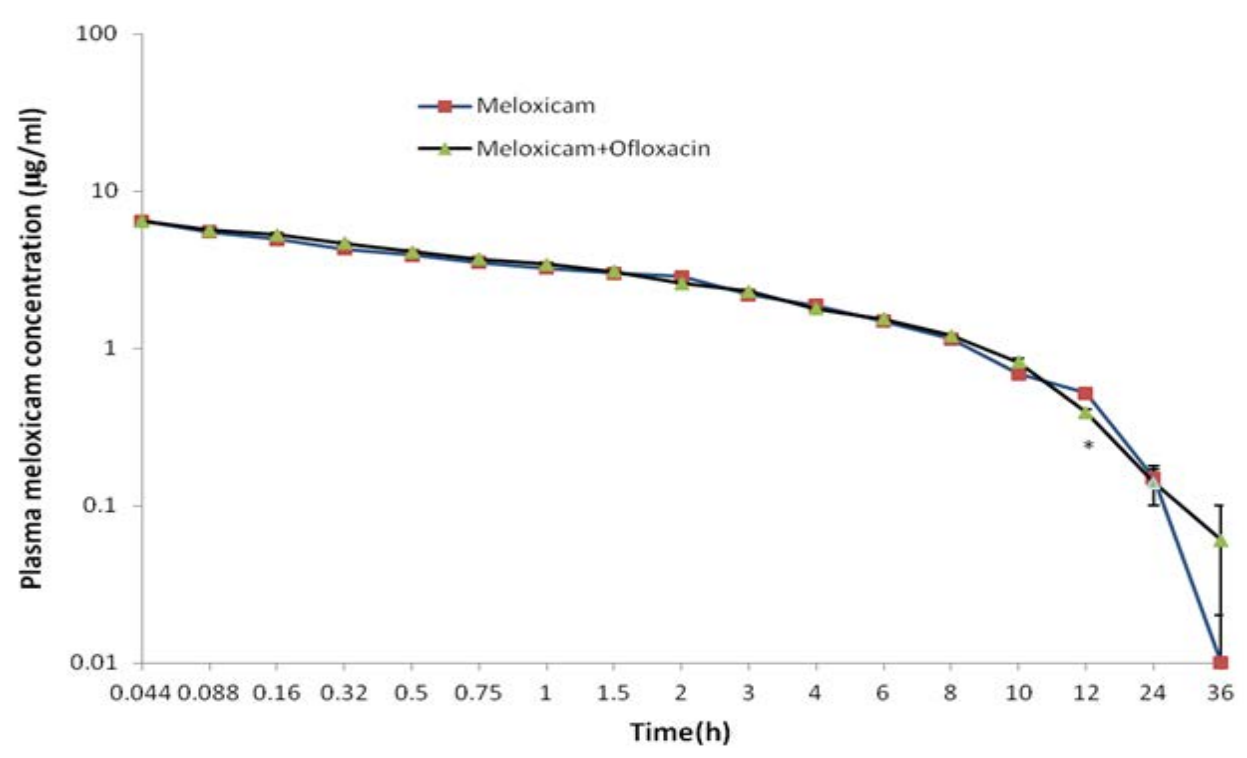

Figure 2: Semi logarithmic plot of comparative meloxicam levels following a single intravenous administration of meloxicam $(0.5 \mathrm{mg} / \mathrm{kg})$ alone and after concurrent administration of meloxicam $(0.5 \mathrm{mg} / \mathrm{kg})$ and ofloxacin $(7.5 \mathrm{mg} / \mathrm{kg})$ in cattle. Data presented are mean $\pm \mathrm{SE}$ of five animals.

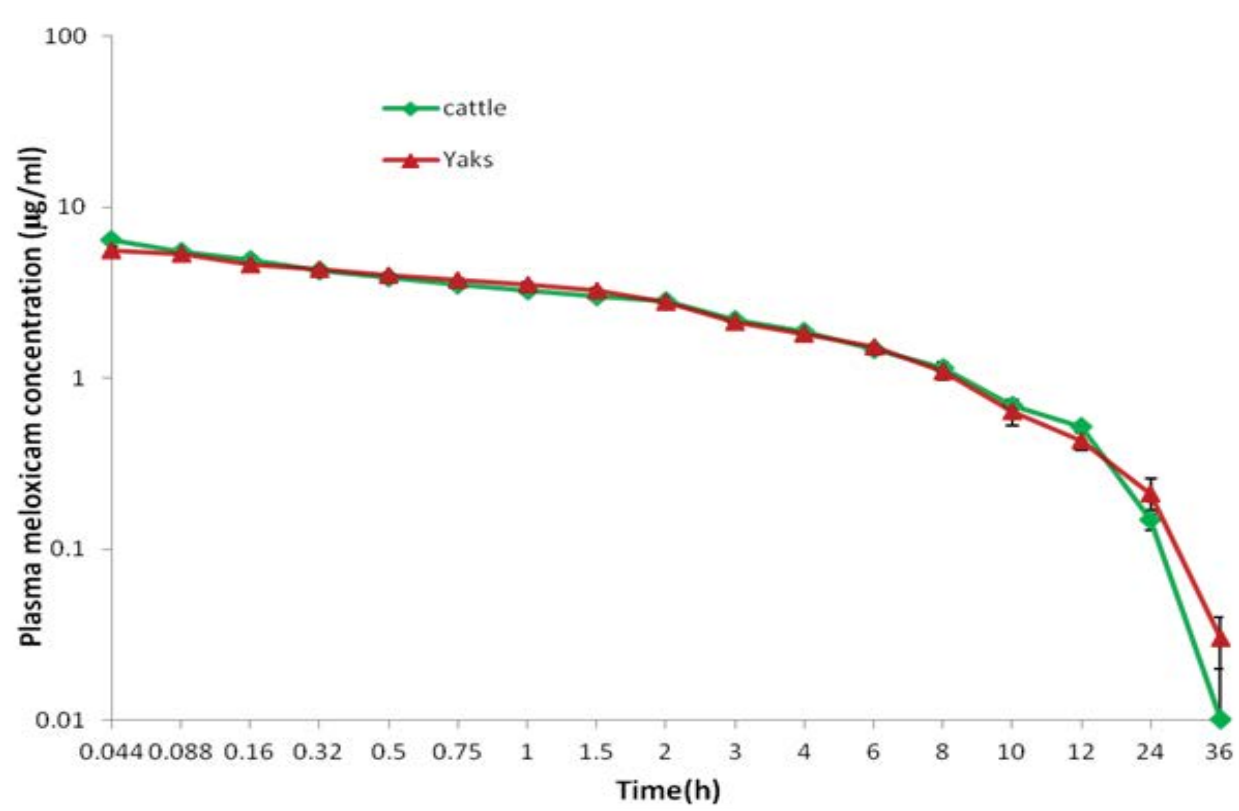

Figure 3: Semi logarithmic plot of comparative meloxicam levels following a single intravenous administration of meloxicam $(0.5 \mathrm{mg} / \mathrm{kg})$ in yak and cattle. Data presented are mean $\pm \mathrm{SE}$ of five animals.

biexponential equation both in yak and cattle following concurrent administration with ofloxacin also as described earlier for its alone administration and different pharmacokinetic parameters have been summarized in Table 1.

\section{Discussion}

Following single intravenous administration of meloxicam (0.5 mg.kg $\left.{ }^{-1}\right)$ in yak and cattle, its pharmacokinetics was best described by two-compartment open model as in sheep and goats [8], horses [3], duck and turkeys [23] and piglets [9], but has been described by noncompartment model in cattle [6].
Distribution half life of meloxicam after IV administration was $0.21 \pm 0.04 \mathrm{~h}$ in yak and $0.24 \pm 0.06 \mathrm{~h}$ in cattle, thus suggesting rapid distribution of meloxicam both in yak and cattle and these values did not differ significantly between these two species. Compared to yak and cattle, longer distribution half lives of $0.42 \pm 0.08$ and $0.37 \pm 0.10 \mathrm{~h}$, respectively in sheep and goats [8] and $0.70 \mathrm{~h}$ in piglets [9] have been reported which suggest that distribution of meloxicam was faster in yak and cattle compared to the other studied species and these differences may be attributed to species-dependent anatomical, physiological and/ or biochemical variations between different species.

Elimination half-life of meloxicam in the present study in yak 
$(4.65 \pm 0.40 \mathrm{~h})$ and cattle $(5.04 \pm 0.35 \mathrm{~h})$ were almost comparable and did not differ significantly from each other. But it was much shorter compared to $10.85 \mathrm{~h}$ in sheep and $6.73 \mathrm{~h}$ in goats [8], $37.88 \mathrm{~h}$ in buffalo calves [7] and $24 \mathrm{~h}$ in dogs [1]. But on the contrary, comparatively much shorter elimination half-life of $2.7 \pm 0.3 \mathrm{~h}$ in piglets [9] and 2.7 $\pm 0.44 \mathrm{~h}$ in equines [3] has been reported. Thus, these values suggest that compared to yak and cattle, elimination of meloxicam is slower in sheep, goats, buffaloes and dogs and faster in piglets and equines.

The AUC value of meloxicam between yak $\left(25.46 \pm 1.22 \mu \mathrm{g} \cdot \mathrm{ml}^{-1} \cdot \mathrm{h}\right)$ and cattle $\left(26.53 \pm 0.94 \mu \mathrm{g} \cdot \mathrm{ml}^{-1} . \mathrm{h}\right)$ did not differ from each other and were almost comparable to that in dogs $\left(22.9 \mu \mathrm{g} \cdot \mathrm{ml}^{-1} . \mathrm{h}\right)$; [1] but lower than the value in sheep $\left(31.88 \pm 2.97 \mu \mathrm{g} \cdot \mathrm{ml}^{-1}\right)$; [8] and higher than in goats $\left(19.23 \pm 2.23 \mu \mathrm{g} \cdot \mathrm{ml}^{-1}\right)$; [8], equines $\left(14.53 \pm 0.8 \mu \mathrm{g} \cdot \mathrm{ml}^{-1}\right)$; [3] and piglets $(8.03 \pm 1.08)$; [9]. Mean residence time (MRT) of meloxicam following IV administration in yak $(6.50 \pm 0.59 \mathrm{~h})$ and cattle $(6.97 \pm$ $0.43 \mathrm{~h}$ ) were almost comparable but were much shorter compared to the MRT values of $15.13 \pm 1.67 \mathrm{~h}$ in sheep and $9.37 \pm 0.83 \mathrm{~h}$ in goat [8], $34.8 \mathrm{~h}$ in dog [1] and longer than in piglets (3.5h \pm 0.3$)$; [9] and the MRT values corroborated well with the observed and reported elimination half life values of this drug in different species of animals.

Apparent volume of distribution $\left(\mathrm{Vd}_{\text {area }}\right)$ of meloxicam in yak $\left(1.97 \pm 0.11 \mathrm{~L}^{\mathrm{kg}} \mathrm{kg}^{-1}\right)$ and cattle $\left(2.05 \pm 0.09 \mathrm{~L} . \mathrm{kg}^{-1}\right)$ were several folds higher compared to that in sheep and goat $(0.25 \pm 0.02$ and $0.26 \pm$ 0.01 , respectively); [8] and equines $\left(0.16 \pm 0.002{\mathrm{~L} . \mathrm{kg}^{-1}}^{-1}\right.$ and $0.25 \mathrm{~L} . \mathrm{kg}$ $\left.{ }^{1}\right) ;[3,5]$. Therefore, results of the present study suggest that compared to the limited penetration of meloxicam in sheep, goat and equines, meloxicam seems to be very widely distributed into different body tissues and fluids of yak and cattle as the $\mathrm{Vd}_{\text {area }}$ value of $>1.0 \mathrm{~L} / \mathrm{kg}$ indicate excellent tissue penetration ability of meloxicam in yak and cattle and, therefore, it may be of great clinical utility in treatment of almost all systemic inflammatory conditions in both the test species.

Values of $\mathrm{f}_{\mathrm{c}}, \mathrm{V}_{\mathrm{c}}$ and $\mathrm{T} / \mathrm{P}$ in yak were $0.35 \pm 0.02,0.33 \pm 0.22 \mathrm{~L}^{\mathrm{kg}} \mathrm{kg}^{-1}$ and $2.13 \pm 0.44$ while the corresponding values in cattle were $0.73 \pm$ $0.11,1.47 \pm 0.03 \mathrm{~L} \cdot \mathrm{kg}^{-1}$ and $0.59 \pm 0.36$, respectively, and these values differed significantly between yak and cattle. These attributes suggest that meloxicam stays less in the central compartment and more in the peripheral compartment in yak while there was an opposite trend in cattle. In view of the almost similar values of distribution and elimination half-lives, apparent volume of distribution and mean residence time in yak and cattle, it is difficult to offer any logical explanation for significant differences in the values of $f_{c}, V_{c}$ and T/P.

Total body clearance $\left(\mathrm{Cl}_{\mathrm{B}}\right)$ values of meloxicam in yak $(0.35 \pm 0.02$ L.h $\left.\mathrm{h}^{-1} \mathrm{~kg}^{-1}\right)$ and cattle $\left(0.29 \pm 0.01 \mathrm{~L} . \mathrm{h}^{-1} \mathrm{~kg}^{-1}\right)$ were almost comparable in both the species but were comparatively higher than the values

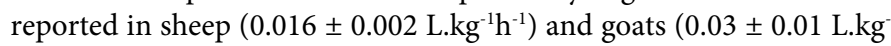
${ }^{1} \mathrm{~h}^{-1}$ ) [8] and $0.061 \pm 0.008 \mathrm{~L}^{\mathrm{kg}} \mathrm{kg}^{-1} \mathrm{~h}^{-1}$ in piglets [9]. The $\mathrm{Cl}_{\mathrm{B}}$ values also substantiate rapid elimination of meloxicam in yak and cattle and thus shorter elimination half life of meloxicam in yak and cattle compared to the other ruminant species.

Following concurrent administration of meloxicam and ofloxacin in yak and cattle, plasma meloxicam levels and its pharmacokinetic determinants describing the major distribution and elimination characteristics were found to be almost comparable to those observed after single IV bolus dose and did not differ significantly from each other except significantly lower values of T/P $(0.61 \pm$ $0.11)$ and $V_{p}(1.07 \pm 0.23 \mathrm{~L} / \mathrm{kg})$ and higher value of $\mathrm{V}_{c}(1.47 \pm 0.04$ $\mathrm{L} / \mathrm{kg}$ ) after concurrent administration of meloxicam and ofloxacin compared to the corresponding values of $2.13 \pm 0.44,1.97 \pm 0.11 \mathrm{~L} /$ $\mathrm{kg}$ and $0.33 \pm 0.22 \mathrm{~L} / \mathrm{kg}$, respectively in yak after single intravenous bolus dose administration while no such differences were observed in cattle. Significant differences between some of the attributes between meloxicam alone and its concurrent administration with ofloxacin in yak suggest possibility of some pharmacokinetic interaction but it requires further detailed studies to unravel the plausible explanation. Our findings in yak are in agreement with the observations on altered PK variables in goats $[24,25]$. But are contrary to our observations in goats when meloxicam was administered concurrently with ofloxacin [24].

\section{Dosage regimens}

Effective plasma concentration of meloxicam has been reported to be $0.73 \mu \mathrm{g} \cdot \mathrm{ml}^{-1}$ in horses [4]. In another study using human whole blood, meloxicam has been reported to inhibit $50 \%$ of COX-1 activity $\left(\mathrm{IC}_{50}\right)$ at $1.15 \mu \mathrm{g} \cdot \mathrm{ml}^{-1}$ while the $\mathrm{IC}_{50}$ for COX-2 was $0.088 \mu \mathrm{g} \cdot \mathrm{ml}^{-1}$ in human blood [26]. Following single IV bolus dose of meloxicam $\left(0.5 \mathrm{mg}^{-\mathrm{kg}^{-1}}\right)$ in the present study, mean plasma concentrations were found to be 5.60 $\mu \mathrm{g} \cdot \mathrm{ml}^{-1}$ and $6.26 \mu \mathrm{g} \cdot \mathrm{ml}^{-1}$ at $2.5 \mathrm{~min}$ and $0.21 \mu \mathrm{g} \cdot \mathrm{ml}^{-1}$ and $0.15 \mu \mathrm{g} \cdot \mathrm{ml}^{-1}$ at 24 $\mathrm{h}$, respectively in yak and cattle; thus revealing presence of meloxicam in blood of treated animals much above the $\mathrm{IC}_{50}$ value against COX-2 for more than $24 \mathrm{~h}$. Taking into considerations the effective plasma concentration of $0.088 \mu \mathrm{g} \cdot \mathrm{ml}^{-1}$ [26] and pharmacokinetic determinants of meloxicam in yak and cattle, loading and maintenance doses of meloxicam were calculated and found to be 1.05 and $0.88 \mathrm{mg} \cdot \mathrm{kg}^{-1}$ body weight for yak and 0.97 and 0.79 mg.kg ${ }^{-1}$ body weight for cattle and be repeated at $12 \mathrm{~h}$ interval in both the species and these values can be rounded off to 1.0 and $0.8 \mathrm{mg} / \mathrm{kg}$ body weight. Concurrent intravenous administration of meloxicam with ofloxacin did not reveal any significant pharmacokinetic interaction between the two drugs both in yak and cattle, thus any adjustment in the dosage regimens of meloxicam are not required.

\section{Conclusion}

Based on the results of present disposition kinetic studies of meloxicam in yak and cattle and interaction studies between meloxicam and ofloxacin, it may be inferred that different pharmacokinetic parameters do not differ significantly between yak and cattle except $\mathrm{K}_{12} /$ $\mathrm{K}_{21}, \mathrm{f}_{\mathrm{c}}$ and $\mathrm{V}_{\mathrm{c}}$ values which were significantly lower and the values of $\mathrm{V}_{\mathrm{p}}$ and $\mathrm{T} / \mathrm{P}$ were significantly higher in yak compared to those in cattle. Except for significant alterations in values of $\mathrm{V}_{c}, \mathrm{~V}_{\mathrm{p}}$ and $\mathrm{T} / \mathrm{P}$ in yak but not in cattle, ofloxacin did not significantly alter the pharmacokinetic determinants of meloxicam which are important for computation of dosage. Therefore, adjustment in dosage regimen of meloxicam is not warranted in either of the species, if to be used concurrently with ofloxacin.

\section{Acknowledgement}

Authors are grateful to the Director, ICAR-National Research Centre on Yak, Dirang, Arunachal Pradesh, India for according the necessary permission for collection of blood samples and providing necessary laboratory facilities for undertaking the research work.

\section{References}

1. Busch U, Schmid J, Heinzel G, Schmaus H, Baierl J, et al. (1998) Pharmacokinetics of meloxicam in animals and the relevance to humans. Drug Metab Dispos 26: 576-584.

2. European Agency for the Evaluation of Medicinal Products (EMEA) Committee for Veterinary Medicinal Products (2009) Meloxicam: Maximum Residue Limit (MRL) Summary Report.

3. Lees P, Sedgwick AD, Higgins AJ, Pugh KE, Busch U (1991) Pharmacodynamics and pharmacokinetics of meloxicam in horse. Br Vet J 147: 97-108. 
Citation: Ahmed FUA, Yadav RS, Garg SK (2015) Comparative Disposition Kinetics of Meloxicam Following a Single Intravenous Bolus Dose and Its Concurrent Administration with Ofloxacin in Yak and Cattle. J Bioanal Biomed 7: 197-202. doi:10.4172/1948-593X.1000144

4. Toutain PL, Reymond N, Laroute V, Garcia P, Popot MA, et al. (2004) Pharmacokinetics of meloxicam in plasma and urine of horses. Am J Vet Res 65: $1542-1547$

5. Sinclair MD, Mealey KL, Matthews NS, Peck KE, Tylor TS, et al. (2006) Comparative pharmacokinetics of meloxicam in clinically normal horses and donkeys. Am J Vet Res 67: 1082-1085.

6. Malreddy PR, Coetzee JF, Kukanich B, Gehring R (2013) Pharmacokinetics and milk secretion of gabapentin and meloxicam co-administered orally in Holstein-Friesian cows. J Vet Pharmacol Ther 36: 14-20.

7. Mody SK, Patel HA (2007) HPLC analysis and pharmaciokinetics of meloxicam in buffalo calves. J Vet Pharmacol Toxicol 6: 15-18.

8. Shukla M, Singh G, Sindhura BG, Telang AG, Rao GS, et al. (2007) Comparative plasma pharmacokinetics of meloxicam in sheep and goats following intravenous administration. Comp Biochem Physiol C Toxicol Pharmacol 145: 528-532.

9. Fosse TK, Haga HA, Horrmazabal V, Haugejorden G, Horsberg TE, et al. (2008) Pharmacokinetics and pharmacodynamics of meloxicam in piglets. $J$ Vet Pharmacol Ther 31: 246-252.

10. Ziegler LE, Pvelicita T, Bluhmki E, Turck D, Scheuerer S, et al. (2001) Meloxicam: a review of its pharmacokinetics, efficacy and tolerability following intramuscular administration. Inflamm Res 50: S5-9.

11. Meineke I, Turck D (2003) Population pharmacokinetic studies of meloxicam in rheumatoid arthritis patients. Br J Clin Pharmacol 55: 32-38.

12. Chinnadurai SK, Messenger KM, Papich MG, Harms CA (2014) Meloxicam pharmacokinetic using non-linear mixed effect modelling in ferrets after single subcutaneous administration. J Vet Pharmacol Ther 37: 382-387.

13. Langtry HD, Lamb HM (1998) Levofloxacin: its use in infections of the respiratory tract, skin, soft tissues and urinary tract. Drugs 56: 487-515.

14. Hirai S, Tanaka K, Makino S, Narita H (1989) Adverse drug interaction between pyridonecarboxylic acids and non steroidal anti-inflammatory drugs: Convulsions after oral or intracerebral administration in mice. Yakugaku Zasshi 109: 119-126.
15. Parikh V, Shivprakash, Patel D, Gandhi TP, Patel RB, et al. (1996) Effect of aspirin on single and multiple dose pharmacokinetics of ciprofloxacin in rabbits. Indian J Pharmacol 28: 25-28.

16. Dumka VK, Sandhu HS, Rajput N (2007) Effect of gatifloxacin on the pharmacokinetics of meloxicam in buffalo calves. Indian J Anim Sci 77: 12701272.

17. Toppo R, Roy BK, Mishra AK (2011) Effects of concurrent administration of meloxicam on pharmacokinetic parameters of enrofloxacin in turkeys. J Bioanal Biomed 3: 108-112.

18. Ahmed FA, Mohan P, Barua CC, Dutta DJ (2005) Effect of intramuscular diclofenac sodium on pharmacokinetics of intravenous enrofloxacin in calves. Indian J Pharmacol 37: 189-190.

19. Dasandi B, Shivprakash, Saroj H, Bhat KM (2002) LC determination and pharmacokinetics of meloxicam. J Pharm Biomed Anal 28: 999-1004.

20. Baggot JD (1977) Principles of drug disposition in domestic animals: The basis of veterinary clinical pharmacology. WB Saunders Co, Philadelphia, USA.

21. Gibaldi M, Perrier D (1982) Pharmacokinetics. (2 ${ }^{\text {nd }}$ Edition) Marcel-Dekker Inc, New York, USA.

22. Snedecor GW, Cochran WG (1967) Statistical Methods. Oxford and IBH publishing Co, New Delhi.

23. Baert K, De Backer $P$ (2003) Comparative pharmacokinetics of three nonsteroidal anti-inflammatory drugs in five bird species. Comp Biochem. Physiol C Toxicol Pharmacol 134: 25-33.

24. Yadav RS, Garg SK, Rahal A (2014) Influence of ofloxacin on the disposition kinetics of meloxicam following single intravenous administration in goats. Veterinarski Arhiv 84: 625-635.

25. Verma R, Choudhary GK, Sajan R (2007) Pharmacokinetics of enrofloxacin and ciprofloxacin as a metabolite and its interaction with meloxcam in Jamunapari goats. J Vet Pharmacol Toxicol 6: 11-14.

26. Pairet M, Van Ryn J, Schierok H, Mauza A, Trummlitz G, et al. (1998) Differential inhibition of cyclooxygenase- 1 and 2 by meloxicam and its 4 '- isomer. Inflamm Res 47: 270-276. 